\title{
Volden som rammer kvinner og volden som rammer menn - to ulike verdener?
}

\section{Resultater fra anonym spørreundersøkelse blant 40-42-åringer i 1990-1994 i Akershus og Buskerud}

\author{
Arne Hjemmen, Odd Steffen Dalgard ${ }^{1}$ og Sidsel Graff-Iversen ${ }^{2}$ \\ ${ }^{1}$ Institutt for allmennmedisin og samfunnsmedisin, Universitetet $i$ Oslo \\ ${ }^{2}$ Nasjonalt Folkehelseinstitutt \\ Korrespondanse: Arne Hjemmen, Øvre Måsan 33, 1385 Asker, e-post: naah@online.no
}

\begin{abstract}
SAMMENDRAG
Artikkelen beskriver resultater av en anonym spørreundersøkelse av i alt 11.666 kvinner og 10.036 menn i aldersgruppen 40-42 år gjennomført i tre omganger, henholdvis i 1990-91 i Akershus, 1993 i Buskerud og i 1994 igjen i Akershus. Undersøkelsen viser at $20,2 \%$ av kvinnene og $18,5 \%$ av mennene har vært utsatt for vold en eller flere ganger i løpet av livet. Mens de fleste kvinner har vært utsatt for vold i hjemmet (74\%), har de fleste menn (51\%) vært utsatt for vold andre steder enn i hjemstedskommunen. Tilsvarende er de fleste av voldsutøverne når det gjelder kvinner et familiemedlem eller samboer, mens det for mennenes vedkommende oftest dreier seg om ukjente. Det er klar sammenheng mellom vold og psykiske helseproblemer, idet de voldsutsatte har en signifikant større andel personer med en høy skåre på HSCL-25, et instrument som måler angst/depresjon. Både hos menn og kvinner er de som har vært utsatt for seksualisert vold mest utsatt, idet over $40 \%$ har psykiske helseproblemer, sammenliknet med gjennomsnittlig ca. $15 \%$ i totalutvalget. De som har vært utsatt for vold har vært utsatt for flere andre typer livsbelastninger siste år enn de øvrige, og dette kan i betydelig grad forklare den økede hyppighet av psykiske helseproblemer hos voldsofrene. Den nærmere sammenheng mellom vold og andre livsbelastninger lar seg imidlertid ikke utrede i en tverrsnittsundersøkelse som denne.
\end{abstract}

\section{Hjemmen A, Dalgard OS, Graff-Iversen S. Violence to women and violence to men -} two different worlds? Nor J Epidemiol 2002; 12 (3): 275-280.

\section{ENGLISH SUMMARY}

The paper gives the results of an anonymous survey based on questionnaire to 11.666 women and 10.036 men in the age group 40-42 years, undertaken in 1990-91 in Akershus county, in 1993 in Buskerud county and in 1994 again in Akershus county. The survey shows that $20.2 \%$ of women and $18.5 \%$ of men have been exposed to violence, one or several times, during their lives. Wheras women mainly have been exposed to violence in their home (74\%), most of the men $(51 \%)$ have been exposed to violence outside their home community. Correspondingly, most of the perpetrators of violence among the women are family members or cohabitants, whereas among the men the perpetrators are persons unknown to the victim. There is a significant relationship between being exposed to violence and mental health problems, as measured by HSCL-25. In both genders, sexualized violence shows the strongest correlation with mental health problems, with a prevalence of HSCL- $25>1.75$ higher than $40 \%$, compared to about $15 \%$ in the total sample. The victims of violence have also to a greater extent been exposed to other negative life events last year, and this explains a considerable part of the association between violence and mental health problems in the present sample. In a cross-sectional investigation like the present, it is, however, not possible to explain further the relationship between violence and other negative life events.

\section{INNLEDNING}

Oppmerksomheten omkring vold og de fysiske og psykiske helseproblemer som skyldes vold, har fått stadig større aktualitet i Norge, og vold oppfattes i dag som et stort folkehelseproblem, med alvorlige konsekvenser i form av fysisk og psykisk helseskade (1). I tillegg til det direkte fysiske traumet som i alvorligste fall kan medføre døden, er volden assosiert med en rekke fysiske og psykologiske plager som: Angst, depresjon, posttraumatisk stress syndrom, andre psykiatriske lidelser, spiseforstyrrelser, alkohol- og stoffavhengighet, videre kroniske smertetilstander, øvrige muskel-skjelettsymptomer, kronisk hodepine, kroniske abdominalsmerter og bekkensmerter (2). At vold, og kanskje spesielt vold mot kvinner, er assosiert med både psykiske 
og somatiske helseproblemer er vist $\mathrm{i}$ en rekke undersøkelser (3-7), men det er likevel vanskelig å si noe sikkert om den helsemessige betydning av vold som isolert fenomen. Som blant annet vist av Kessler og medarbeidere (8), er nemlig vold ofte assosiert med andre traumatiske forhold, som i seg selv kan være en helsebelastning. I den store amerikanske "komorbiditetsundersøkelsen”, der 8098 personer ble intervjuet, viste det seg at vold i barndommen var sterkt assosiert med både tap av foreldre, sinnslidelser blant foreldrene og ulykker og andre traumatiske hendelser. Selv om hvert enkelt av disse forhold var knyttet til øket risiko for senere utvikling av psykiske helseproblemer, ble effekten av det enkelte traume sterkt redusert når en kontrollerte for effekten av de andre. Likevel ble det tilbake en signifikant effekt av de enkelte traumer, også vold. Konklusjonen blir altså at vold i seg selv har en negativ effekt på helsa, men at det er tilknytningen til en rekke andre uheldige forhold som gir de dramatiske utslag. Tilsvarende vet en at de voksne som har vært utsatt for vold, og som har psykiske helseproblemer, ofte lever under vanskelige sosiale forhold, f.eks. fattigdom og ensomhet, som i seg selv kan være en helsebelastning. Alt dette betyr at volden, som en viktig risikofaktor $\mathrm{i}$ forhold til både psykisk og fysisk helse, må studeres og behandles som en del av et større hele, der ulike uheldige forhold griper inn i hverandre.

Volden rammer ikke bare offeret for volden, men har også alvorlige konsekvenser for samfunnet for øvrig. Nyhets- og massemedias ofte «tabloidiserte» fremstilling av vold og forekomst av vold kan bidra til å skape stereotype og dramatiske bilder om voldsfare og om den enkeltes egen risiko for å bli utsatt for vold. Dette igjen kan skape unødig voldsfrykt i befolkningen og gi utrygghet blant folk i sin alminnelighet for selv å bli et offer for vold. Ved å skape en mer eller mindre ubegrunnet frykt for å bli utsatt for vold, vil det kunne berøre og innskrenke enkeltmenneskers personlig livsutfoldelse, selvrealisering og sosiale deltagelse. Dette gjelder kan hende ikke minst i den eldre del av befolkningen.

Formålet med den foreliggende undersøkelse har vært å fremskaffe kunnskap om utbredelsen av ulike typer vold hos begge kjønn, og om voldens betydning for den psykiske helse. Slik kunnskap er viktig å formidle til de profesjonelle fagmiljøer innenfor helse-, sosial-, skole- og undervisningssektoren samt kriminalomsorgen (9). Videre vil det være behov for folkeopplysning om vold for å motvirke de effekter som bl.a. nyhets- og massemedias ofte «tabloidiserte» fremstilling har på befolkningens trygghet og sikkerhet. Befolkningens kunnskap om vold bør økes slik at man tydeligere ser hvor i samfunnet vold skjer og hvordan volden egentlig er. I tillegg vil man ved å øke den positive og støttende sosiale kontroll mennesker $\mathrm{i}$ mellom, bidra til å forebygge at vold skjer. Ved å kunne se volden i nærmiljøet der folk lever og bor, kan man også lettere se dem som er voldens offer. Svært ofte er disse tause og anonyme. Ved å "se" dem, og dette er ikke minst en utfordring for de profesjonelle hjelperne, kan flere av ofrene lettere få støtte og bistand til å søke profesjonell hjelp så tidlig at det kan være mulig å forebygge de mest alvorlige fysiske og psykologiske konsekvenser av volden.

\section{Materiale OG Metode}

Da Statens Helseundersøkelser (SHUS) som en del sitt 40-årings program, gjennomførte hjerte-karundersøkelsen i Akershus i 1990-91, i Buskerud i 1993 og igjen i Akershus i 1994, ble det gjennomført en anonym spørreskjemaundersøkelse for å kartlegge psykososiale forhold, herunder vold, og psykisk helse. I delundersøkelsen i Akershus 1994 inkluderte man også spørsmål om arbeid og trygd, kroniske smerter, selvrapportert helsenivå, forbruk av smertestillende og beroligende medisin og alvorlige livsbelastninger. Spørreskjemaene med informasjonsskriv og svarkonvolutt var sendt ut på forhånd $\mathrm{i}$ posten sammen med invitasjon til hjerte-karundersøkelsen. Skjemaene ble innsamlet ved fremmøte til hjerte-karundersøkelsen. Resultater fra delundersøkelsen Akershus 1990-91 er publisert i Tidsskrift for Den norske lægeforening (10).

\section{Representativitet}

I alt fikk vi svar fra 11.666 kvinner og 10.036 menn, totalt 21.702 personer (11). Som det fremgår av tabell 1 har $67 \%$ av kvinner og $65 \%$ av menn som møtte til hjerte-karundersøkelsen, deltatt i spørreundersøkelsen. Av totalt antall inviterte, det vil si hele gruppen 40-42 år, har $48 \%$ kvinner og $41 \%$ menn deltatt. Lav svarprosent $\mathrm{i}$ forhold til hele gruppen påvirker trolig resultatene av spørreundersøkelsen.

Ved å sammenligne materialet fra spørreundersøkelsen med demografiske data fra Statistisk Sentralbyrå (SSB) viser materialet en større andel som bor sammen med ektefelle og en lavere andel som bor alene, sammenlignet med SSBs folketellingsdata. Blant deltakerne i spørreundersøkelsen har også flere høyere utdannelse (høyskole- og universitetsnivå) og færre har folkeskole/grunnskole som høyeste utdannelse, sammenlignet med hele gruppen 40-42 åringer i befolkningen. Det er således holdepunkter for at materialet fra spørreundersøkelsen omfatter en gruppe personer som er høyere utdannet, som i større andel er gifte og som i mindre andel bor alene, sammenlignet med hele befolkningsgruppen på samme alder. Ut fra det en vet om sammenhengen mellom psykisk helse og sosiodemografiske variable, peker dette i retning av at utvalget har noe bedre psykisk helse enn den aktuelle totalbefolkning.

Tabell 1. Deltagelse i anonym spørreskjemaundersøkelse i 1990-91, 1993 og 1994.

\begin{tabular}{lccccc}
\hline & $\begin{array}{c}\text { antall } \\
\text { inviterte }\end{array}$ & $\begin{array}{c}\text { møtt } \\
\text { antall }\end{array}$ & $\begin{array}{c}\text { svar } \\
\text { antall }\end{array}$ & $\begin{array}{c}\text { prosent } \\
\text { av møtte }\end{array}$ & $\begin{array}{c}\text { prosent av } \\
\text { inviterte }\end{array}$ \\
\hline Kvinner & 24.157 & 17.502 & 11.666 & 67 & 48 \\
Menn & 24.355 & 15.455 & 10.036 & 65 & 41 \\
\hline
\end{tabular}




\section{RESULTATER}

\section{Psykisk helse}

Psykisk helse, psykiske helseplager og psykisk stress er et av hovedelementene i spørreundersøkelsen. En har brukt Hopkins Symptom Check List (HSCL-25) som omfatter 25 spørsmål om angst, depresjon og somatisering. Det oppfattes som "psykiske helseproblemer" når det foreligger en gjennomsnittsskår lik eller over 1,75. Andelen av respondentene (i \%) i spørreundersøkelsen med HSCL-25 skår lik eller over 1,75, fremgår av tabell 2. Tabellen viser at 9,9\% av mennene og 18,5\% av kvinnene har psykiske plager og besvær. I alle delundersøkelser er hyppigheten av psykiske plager signifikant høyere blant kvinner enn menn, mens det ikke er noen signifikant forskjell mellom undersøkelsene.

\section{Forekomst av ulike voldstyper}

Til sammen 20,2\% av kvinner og 18,5\% av menn har svart ja på spørsmål om de noen gang hadde vært utsatt for vold utenom uhell og barneslagsmål. Som det fremgår av tabell 3 er menn hyppigere utsatt for slagsmål, ran og overfall, mens kvinner er hyppigere utsatt for seksuell vold/misbruk, mishandling, samt psykisk vold og alvorlige trusler. Forskjellen mellom kvinner og menn er statistisk signifikant.

\section{Enkelthendelser eller gjentagelse av vold?}

Som det fremgår av tabell 4, er de fleste tilfeller av vold hos kvinner og hos menn enkelthendelser: $12,4 \%$ av kvinnene og $13,9 \%$ av mennene svarte at de hadde vært utsatt for en eller flere enkeltepisoder med vold. Når det gjelder regelmessig vold av varighet utover tre måneder svarte $4,5 \%$ av kvinnene og $1,5 \%$ av mennene at de hadde vært utsatt for slik vedvarende vold. Også her er forskjellen mellom kvinner og menn statistisk signifikant.

\section{Sted for voldsskaden}

Interessant er det også å se hvor volden skjedde. I spørreskjemaet har man spurt om volden skjedde i eget hjem, i nabolaget, utenfor hjemkommunen eller i utlandet. Som det fremgår av tabell 5 er kvinner hyppigst utsatt for vold i eget hjem, 74\%, mens menn er hyppigst utsatt for vold utenfor hjemkommunen eller i utlandet, 51\%. Forskjellen mellom kvinner og menn er statistisk signifikant.

\section{Relasjon mellom voldsutoveren og offeret}

I spørreskjemaet har man likeledes spurt om voldsutøveren var ukjent, perifer bekjent, godt kjent eller ektefelle, samboer eller familiemedlem. Tabell 6 angir hvilken relasjon voldsofferet har/har hatt til voldsutøveren. Resultatet viser at menn hyppigst er utsatt for vold fra en ukjent person, $76 \%$. Tilsvarende er kvinner hyppigst utsatt for vold fra en nærstående person som ektefelle, samboer eller familiemedlem, 67\%. Forskjellen mellom menn og kvinner er statistisk signifikant.
Tabell 2. Psykiske helseplager (HSCL-25 > 1,75), prosent).

\begin{tabular}{lccc}
\hline & $\begin{array}{c}\text { Menn } \\
(\mathrm{N}=8.297)\end{array}$ & $\begin{array}{c}\text { Kvinner } \\
(\mathrm{N}=9.643)\end{array}$ & $\begin{array}{c}\text { Signifi- } \\
\text { kansnivå }\end{array}$ \\
\hline Akershus 1990-91 & 8,3 & 17,0 & $\mathrm{P}<0,001$ \\
Buskerud 1993 & 11,4 & 20,0 & $\mathrm{P}<0,001$ \\
Akershus 1994 & 10,6 & 18,1 & $\mathrm{P}<0,001$ \\
Totalt & $\mathbf{9 , 9}$ & $\mathbf{1 8 , 5}$ & $\mathbf{P}<\mathbf{0 , 0 0 1}$ \\
Signifikansnivå & $\mathrm{NS}$ & $\mathrm{NS}$ & \\
\hline
\end{tabular}

Tabell 3. Forekomst av voldstyper, pr. 1000.

\begin{tabular}{lccc}
\hline & $\begin{array}{c}\text { Menn, } \\
(\mathrm{N}=10.036)\end{array}$ & $\begin{array}{c}\text { Kvinner, } \\
(\mathrm{N}=11.666)\end{array}$ & $\begin{array}{c}\text { Signifi- } \\
\text { kansnivå }\end{array}$ \\
\hline Vold, i alt & 185 & 202 & $\mathrm{P}<0,01$ \\
Slagsmål, ran, overfall & 102 & 22 & $\mathrm{P}<0,001$ \\
Seksuell vold/misbruk & 10 & 63 & $\mathrm{P}<0,001$ \\
Mishandling & 20 & 65 & $\mathrm{P}<0,001$ \\
Psykisk vold, trusler & 58 & 84 & $\mathrm{P}<0,01$ \\
\hline
\end{tabular}

Tabell 4. Voldsskade, enkelthendelse eller gjentagelse av vold, pr. 1000 .

\begin{tabular}{lccc}
\hline & $\begin{array}{c}\text { Menn } \\
(\mathrm{N}=10.036)\end{array}$ & $\begin{array}{c}\text { Kvinner } \\
(\mathrm{N}=11.666)\end{array}$ & $\begin{array}{c}\text { Signifi- } \\
\text { kansnivå }\end{array}$ \\
\hline Vold, i alt & 185 & 202 & $\mathrm{P}<0,01$ \\
Vold, enkeltepisoder & 139 & 124 & $\mathrm{P}<0,05$ \\
Regelmessig vold & 15 & 45 & $\mathrm{P}<0,001$ \\
\hline
\end{tabular}

Tabell 5. Sted for voldsskaden, prosent.

\begin{tabular}{lccc}
\hline & $\begin{array}{c}\text { Menn } \\
(\mathrm{N}=1.805)\end{array}$ & $\begin{array}{c}\text { Kvinner } \\
(\mathrm{N}=2.329)\end{array}$ & $\begin{array}{c}\text { Signifi- } \\
\text { kansnivå }\end{array}$ \\
\hline I eget hjem & 19 & 74 & $\mathrm{P}<0,01$ \\
I nabolaget & 31 & 11 & $\mathrm{P}<0,01$ \\
Annen kommune/utlandet & 51 & 15 & $\mathrm{P}<0,05$ \\
\hline
\end{tabular}

Tabell 6. Relasjon mellom voldsutøver og voldsoffer, prosent.

\begin{tabular}{lccc}
\hline & $\begin{array}{c}\text { Menn } \\
(\mathrm{N}=1.805)\end{array}$ & $\begin{array}{c}\text { Kvinner } \\
(\mathrm{N}=2.329)\end{array}$ & $\begin{array}{c}\text { Signifi- } \\
\text { kansnivå }\end{array}$ \\
\hline Gift/samboer, familie & 13 & 67 & $\mathrm{P}<0,001$ \\
Godt kjent & 11 & 12 & $\mathrm{NS}$ \\
Ukjent & 76 & 21 & $\mathrm{P}<0,001$ \\
\hline
\end{tabular}

En har videre spurt om den som utøvet volden var påvirket av rusmidler. Resultatet fremgår av tabell 7 . De fleste mannlige voldsofre (55\%) har vært påført vold av en person som var påvirket av rusmidler, men 33\% var utsatt for vold fra en edru person. Når det gjelder kvinnene, har de fleste voldsofre (52\%) vært utsatt for edrue voldutøvere, mens $38 \%$ har vært påført vold av en person som var påvirket av rusmidler. Forskjellene er statistisk signifikant.

\section{Vold og psykisk helse}

Tabell 8 viser at vold er knyttet til psykiske helseplager. Som det fremgår har menn som har vært utsatt for seksuell vold/misbruk, og spesielt som barn, størst 
forekomst av psykiske problemer, henholdsvis $44 \%$ og $48 \%$. Det er likeledes stor hyppighet av psykiske problemer ved mishandling (35\%), og psykisk vold/trusler $(32 \%)$ for menn. Blant kvinner har de som har vært utsatt for psykisk vold/trusler høyest forekomst av psykiske problemer (45\%), men som for mennene har også kvinnene høye tall for psykiske problemer ved seksuell vold/misbruk (44\%), og spesielt seksuell vold/misbruk som barn, (44\%), samt ved mishandling $(42 \%)$.

\section{Gjentagelse av vold over tid og psykisk helse}

I spørreundersøkelsen har en kartlagt om volden er én eller flere enkelthendelser, eller om volden har skjedd regelmessig over tid. Som tabell 9 viser, stiger andelen som har psykiske plager både hos menn og kvinner ved økende hyppighet av vold. Høyest forekomst både hos menn og kvinner finnes ved vold som er regelmessig vedvarende over tid. Her er hyppigheten av psykiske plager henholdsvis $41 \%$ og $49 \%$.

\section{Vold og fysiske plager}

Som mål på fysiske plager har en spurt om forekomsten av kroniske smerter i muskler/ledd og den selvopplevde helsetilstand (som omfatter både psykisk og somatisk helse). Både hos kvinner og menn har voldsofrene en signifikant større hyppighet av kroniske smerter i muskler/ledd enn de andre, og igjen skiller menn som har vært seksuelt mishandlet seg ut som den mest belastede gruppe. Også når det gjelder selvopplevd helse skiller voldsofrene seg negativt ut.

Tabell 7. Voldsutøver og påvirkning av rusmidler, prosent.

\begin{tabular}{lccc}
\hline & $\begin{array}{c}\text { Menn } \\
(\mathrm{N}=1.805)\end{array}$ & $\begin{array}{c}\text { Kvinner } \\
(\mathrm{N}=2.329)\end{array}$ & $\begin{array}{c}\text { Signifi- } \\
\text { kansnivå }\end{array}$ \\
\hline Påvirket av rusmidler & 55 & 38 & $\mathrm{P}<0,05$ \\
Ikke påvirket & 33 & 52 & $\mathrm{P}<0,01$ \\
Ukjent & 12 & 10 & $\mathrm{NS}$ \\
\hline
\end{tabular}

Tabell 8. Vold og psykiske helseplager (HSCL-25 >1,75), prosent.

\begin{tabular}{lccc}
\hline & $\begin{array}{c}\text { Menn } \\
(\mathrm{N}=8.306)\end{array}$ & $\begin{array}{c}\text { Kvinner } \\
(\mathrm{N}=9.266)\end{array}$ & $\begin{array}{c}\text { Signifi- } \\
\text { kansnivå }\end{array}$ \\
\hline Vold, i alt & 22 & 37 & $\mathrm{P}<0,001$ \\
Slagsmål, ran, overfall & 18 & 33 & $\mathrm{P}<0,001$ \\
Seksuell vold/misbruk & 44 & 41 & $\mathrm{NS}$ \\
Seksuell vold som barn & 48 & 44 & $\mathrm{NS}$ \\
Mishandling & 35 & 42 & $\mathrm{P}<0,05$ \\
Psykisk vold, trusler & 32 & 45 & $\mathrm{P}<0,001$ \\
Populasjonen & 10 & 19 & $\mathrm{P}<0,001$ \\
\hline
\end{tabular}

Tabell 9. Psykiske helseplager (HSCL-25 $>1,75$ ) og gjentagelse av vold, prosent.

\begin{tabular}{lccc}
\hline & $\begin{array}{c}\text { Menn } \\
(\mathrm{N}=6.439)\end{array}$ & $\begin{array}{c}\text { Kvinner } \\
(\mathrm{N}=6.785)\end{array}$ & $\begin{array}{c}\text { Signifi- } \\
\text { kansnivå }\end{array}$ \\
\hline Vold, i alt & 22 & 37 & $\mathrm{P}<0,001$ \\
Vold, flere enkeltepisoder & 26 & 36 & $\mathrm{P}<0,01$ \\
Regelmessig vold & 41 & 49 & $\mathrm{NS}$ \\
\hline
\end{tabular}

\section{Vold, andre livsbelastninger og psykisk helse}

I undersøkelsen har en også spurt om vedkommende har vært utsatt for andre alvorlige livsbelastninger enn vold, nemlig økonomiske problemer, problemer i forhold til arbeid, familieproblemer og problemer i forhold til andre mennesker. Hvis en ser på andelen som har vært utsatt for mer enn to av disse livsbelastninger siste år, finnes en signifikant statistisk sammenheng mellom det å ha vært utsatt for vold og det å ha vært utsatt for andre livsbelastninger. Spesielt nær er sammenhengen mellom seksuell vold/mishandling og andre livsbelastninger hos menn. Mens $13 \%$ av hele populasjonen av menn har vært utsatt for to eller flere livsbelastninger siste år, gjelder dette hele $63 \%$ av de menn som har vært utsatt for seksuell vold/mishandling. Også for andre typer vold er det klare sammenhenger både for menn og kvinner.

For å finne ut i hvor stor utstrekning sammenhengen mellom vold og psykiske helseproblemer kan forklares ved at voldsofrene også har vært utsatt for andre livsbelastninger, som i seg selv kan bidra til psykiske helseproblemer, har vi gjort en logistisk regresjonsanalyse. Foruten andre livsbelastninger, har vi her også tatt inn utdannelsesnivå som uavhengig variabel, da det spesielt for menn i materialet er en sammenheng mellom seksualisert vold og lav utdannelse, og vi fra tidligere vet at det er en sammenheng mellom lav utdannelse og psykiske helseproblemer. Resultatet av denne analysen fremgår av tabell 10. Sammenhengen mellom vold og psykiske helseplager blir lite påvirket når det kontrolleres for utdannelsesnivå, idet odds ratio forblir stort sett uforandret. Derimot blir sammenhengen betydelig redusert når det også kontrolleres for andre livsbelastninger, spesielt gjelder dette menn som har vært utsatt for seksuell vold.

\section{DISKUSJON OG KONKLUSJON}

Resultatene fra spørreskjemaundersøkelsen er basert på svar fra et utvalg der høyt utdannede og gifte er overrepresentert. Videre er det færre aleneboende menn i materialet enn i sammenliknbare folketellingsdata fra Statistisk Sentralbyrå, idet andelen aleneboende er henholdvis $8 \%$ og $20 \%$. Tolkningen av resultatene fra spørreskjemaundersøkelsen må ta hensyn til seleksjonen i materialet med den usikkerhet som ligger i de demografiske dataen nevnt ovenfor. Det kan således tenkes at de som svarte er mindre isolerte og har færre voldsskader enn befolkningen.

En styrke ved undersøkelsen er at den bygger på et stort materiale (21.702 personer) og består av tre delundersøkelser som i stor grad viser konsistens i svarene. Dette bidrar til å gi undersøkelsen tyngde. At materialet er så stort har også vært en forutsetning for å kunne dele opp i ulike typer undergrupper av vold.

Menn og kvinner har vært utsatt for vold i omtrent samme grad, idet henholdvis $20,2 \%$ og $18,5 \%$ har vært utsatt for vold én eller flere ganger i livet. Men typen vold er forskjellig. 
Tabell 10. Logistisk regresjon. Avhengig variabel: psykiske helseplager (HSCL-25 > 1,75). Uavhengige variable: utdannelse og andre livsbelastninger.

\begin{tabular}{lccc}
\hline & \multicolumn{3}{c}{ Odds ratio med 95\% konfidensintervall } \\
\cline { 2 - 4 } Justert for : & Ujustert & Utdannelse & $\begin{array}{c}\text { Utdannelse og } \\
\text { livsbelastninger }\end{array}$ \\
\hline Menn & & & \\
Vold, i alt & $4,05(3,13-5,22)$ & $3,94(3,05-5,10)$ & $2,41(1,81-3,20)$ \\
Slagsmål, ran, overfall & $2,46(1,81-3,35)$ & $2,47(1,82-3,38)$ & $1,73(1,22-2,45)$ \\
Seksuell vold/misbruk & $6,86(3,42-13,77)$ & $6,66(3,30-13,44)$ & $2,12(0,98-4,58)$ \\
Mishandling & $5,57(3,31-9,38)$ & $5,19(3,05-8,83)$ & $2,55(1,40-4,65)$ \\
Psykisk vold, trusler & $3,99(2,71-5,88)$ & $3,95(2,66-5,87)$ & $2,05(1,31-3,20)$ \\
Kvinner & & & \\
Vold, i alt & $3,76(3,13-4,51)$ & $3,78(3,15-4,55)$ & $2,38(1,94-2,92)$ \\
Slagsmål, ran, overfall & $2,20(1,43-3,39)$ & $2,36(1,52-3,65)$ & $1,52(0,93-2,49)$ \\
Seksuell vold/misbruk & $3,80(2,91-4,95)$ & $3,82(2,92-4,99)$ & $2,62(1,93-3,55)$ \\
Mishandling & $4,92(3,71-6,53)$ & $4,77(3,59-6,35)$ & $2,63(1,91-3,64)$ \\
Psykisk vold, trusler & $4,27(3,38-5,47)$ & $4,39(3,42-5,64)$ & $2,37(1,79-3,15)$ \\
\hline
\end{tabular}

Slagsmål, ran og overfall er den type vold som menn hyppigst er utsatt for. Menns vold er en eller flere enkeltepisoder. Volden skjer borte, voldsutøveren er ukjent og er hyppig påvirket av rusmidler. Fra massemedias fremstilling kjenner man utallige historier om vold mot menn som skjer i ulike køer; til utesteder/ drikkesteder, i drosjekøer osv.

Seksuell vold, misbruk, mishandling og psykisk vold, alvorlige trusler er typer vold som rammer kvinner (12). Kvinner er hyppigere utsatt for flere gjentatte voldsepisoder og regelmessig vold. Kvinner er hyppigst utsatt for vold i hjemmet. Voldsutøver er hyppigst ektefelle, samboer, partner eller nær familie. Voldsutøver er hyppigere edru enn påvirket av rusmidler.

Tallene fra vår undersøkelse er forholdvis lave sammenliknet med andre undersøkelser om utbredelsen av vold. Særlig kvinnene i disse undersøkelser har vært utsatt for vold, og det gjelder kvinner i alle aldre (13). I følge sveitsiske data er det estimater som indikerer at 1 av 5 jenter er seksuelt misbrukt, og hvor aldersgruppen før 12 år er den hyppigste utsatte for seksuelt misbruk (14). Prevalens av voldtekt i USA angis til 25\%, med en topp i aldersgruppen 18-24 år. Amerikanske data viser videre at vold $\mathrm{i}$ hjemmet eller vold fra partner involverer $20 \%$ av kvinner i løpet av voksenlivet med en topp i insidens mellom 24-32 år (15). Sluttelig utgjør eldrevold i følge disse data 5\% av alle i gruppen 65 år og eldre. Vold i nære og intime relasjoner er det som dominerer, og offerert er kvinner.

Det er vanskelig å si hvorfor våre tall er såpass lave. En mulighet er at materialet er mer representativt enn $i$ andre undersøkelser, og at disse i større grad er basert på selekterte og belastede utvalg. En annen mulighet er at definisjonen på vold varierer, og at innhenting av informasjon på annen måte enn ved spørreskjemaundersøkelser i større grad er egnet til å avdekke vold. Dette virker imidlertid noe tvilsomt, idet nettopp anonymiteten ved den foreliggende spørreskjemaundersøkelse skulle gjøre det lettere å få frem opplysninger om noe så personlig som å ha vært utsatt for vold. Selv om prevalenstallene for vold kan være noe usikre, er imidlertid hovedresultatet $i$ vår undersøkelse at vold hos menn og kvinner arter seg på svært forskjellig måte, og for begges vedkommende viser en sterk sammenheng med psykiske helseproblemer. Både for menn og kvinner øker hyppigheten av psykiske helseproblemer nesten 4 ganger når en har vært utsatt for vold, mest uttalt for seksuell vold hos menn.

Som nevnt innledningsvis er det imidlertid vanskelig å uttale seg om årsakssammenhenger mellom vold og psykiske helseproblemer $i$ en slik tverrsnittsundersøkelse. Dels vil de som har vært utsatt for vold ofte ha vært utsatt også for andre traumatiske opplevelser (8), og dels vil de som har psykiske helseproblemer, og som har vært utsatt for vold, ofte leve under vanskelige sosiale forhold, som i seg selv kan være en belastning på helsa. Når det gjelder det siste, bekrefter vår undersøkelse at det å være voldsoffer henger sammen andre livsbelastninger, som økonomiske problemer, problemer i forhold til arbeid og problemer i forhold til andre mennesker. At sammenhengen mellom vold og psykiske helseproblemer blir betydelig svekket når det kontrolleres for disse andre belastningene, betyr imidlertid ikke at volden er av underordnet betydning. Tvert imot er det nærliggende å anta at de andre livsbelastninger, ikke minst et problematisk forhold til andre mennesker, kan være et resultat av personlige vansker som igjen er en følge av voldsovergrep. Dette samme kan gjelde økonomiske problemer og problemer i forhold til arbeidet. Selv om vår undersøkelsen ikke kan si så mye om årsaksforholdene, viser den imidlertid at voldsofrene ofte sliter med problemer på en rekke områder, og at en må ta hensyn til dette $\mathrm{i}$ behandling og forebygging. 
Et annet forhold som kan gjøre det vanskelig å trekke slutninger om voldens spesifikke betydning for helsa, er at det å ha psykiske helseproblemer i seg selv kan øke sjansen for å bli utsatt for vold. Dette ville i så fall være i tråd med moderne forskning, som i større grad enn tidligere påpeker kjennetegn ved offeret, og ikke bare ved voldsutøveren, som en risikofaktor for vold. Resultater fra den tidligere omtalte "komorbiditetsundersøkelsen" i USA (8), taler imidlertid til en viss grad i mot dette. Her fant en nemlig at kvinner som hadde vært utsatt for vold fra partner, bare hadde en svak tendens til øket hyppighet av psykiske helseproblemer før parforholdet ble inngått. For menn var imidlertid tendensen mer uttalt.

Som tidligere nevnt synes en å stå overfor to ulike verdener hos menn og kvinner når det gjelder vold. Men det blir tilbake en "cross-over"-kategori: Det dreier seg om kvinner som er utsatt for "typisk" menns vold, og vice versa, menn som er utsatt for "typisk" kvinnevold. Det er verdt å merke seg at menn som har vært utsatt for den mer kvinnelige type vold, nemlig seksuell vold, likesom kvinnene oftere har vært utsatt for regelmessig vold, vold i hjemmet og ofte vold påført av en nærstående person.

Allmennlegen er den instans som hyppigst kommer i kontakt med folk med psykiske helseproblemer. Det er da grunn til å minne om at slike problemer ofte kan være knyttet til vold, og at vold kan bidra til en rekke helseplager, som: Angst, depresjon, posttraumatisk stress syndrom, andre psykiatriske lidelser, spiseforstyrrelser, alkohol- og stoffavhengighet, kroniske smertetilstander, øvrige muskel-skjelettsymptomer, kronisk hodepine, kroniske abdominalsmerter og bekkensmerter. Dette er en stor faglig utfordring for allmennlegene: $\AA$ se hva som kan ligge bak symptomene, plagene og lidelsene. Det krever i tillegg til kunnskap, en "fin nese" rent faglig, og "fine neser" skal i slik sammenheng ikke foraktes (16).

\section{REFERANSER}

1. Kvåle G. Vold Et satsningsområde for forebyggende helsearbeid. Tidsskr Nor Lageforen 1994; 114: 9-10.

2. Kirkengen AL. Et ekko av en annen smerte. Legers møte med skjult vold mot kvinner. Tidsskr Nor Loegeforen 1993; 113: 753-4.

3. Holman EA, Silver RC, Waitzkin H. Traumatic life events in primary care patients - A study in an ethnically diverse sample. Arch Fam Med 2000; 9: 802-2.

4. Vostanis P, Tischler V, Cumella S, Bellerby T. Mental health problems and social support among homeless mothers and children victims of domestic and community violence. Int J Soc Psychiatry 2001; 47: 30-40.

5. Weinbaum Z, Stratton TL, Chavez G, Motylewski-Link C, Barrera N, Courtney JG. Female victims of intimate partner physical domestic violence (IPP-DV), California 1998. Am J Prev Med 2001; 21: 313-9.

6. Brokaw J, Fullerton-Gleason L, Olson L, Crandall C, McLaughlin S, Sklar D. Health status and intimate partner violence: A cross-sectional study. Ann Emerg Med 2002; 39: 31-8.

7. Patel V, Andrew G. Gender, sexual abuse and risk behaviours in adolescents: A cross-sectional survey in schools in Goa. Nat Med J India 2001; 14: 263-7.

8. Kessler RC, Davis CG, Kendler KS. Childhood adversity and adult psychiatric disorder in the US National Comorbidity Survey. Psychol Med 1997; 27: 1101-19.

9. Bang L. Vold - en helsepolitisk udfordring og en retsmedicinsk forpligtelse. Tidsskr Nor Lageforen 1993; 113: $1693-4$.

10. Graff-Iversen S, Gjervig T, Lund-Larsen PG, Hjemmen A, Dalgard OS, Holmsen E. Sosialt nettverk, alkoholvaner og voldsskader hos kvinner og menn i Akershus fylke. Tidsskr Nor Laegeforen 1992; 112: 3579-83.

11. Hjemmen A, Dalgard OS, Graff-Iversen S, Gjervig T. Kommunerapporter fra Anonym spørreundersøkelse blant 40-42-åringer i 1990-1994 i Akershus og Buskerud, stensil.

12. Schei B, Muus KM, Bendixen M. Forekomst av seksuelle overgrep blant studenter i Trondheim. Tidsskr Nor Loegeforen 1994; 114: 2491-4.

13. Von Burg MM, Hibbard RA, Domestic violence: A health concern. Indiana Med 1995; 88: 186-90.

14. Halperin DS, Bouvier P, Jaffe PD, Mounoud RL, Pawlak CH. Prevalence of child sexual abuse in Geneva: results of a cross sectional servey. BMJ 1996; 312: 1326-9.

15. Flitcraft A. From public health to personal health: Violence against women across the life span. Ann Intern Med 1995; 123: 800-2.

16. Gulbrandsen P. Fine neser skal ikke foraktes. Tidsskr Nor Laegeforen 2000; 120: 1509. 